\title{
HOOKWORM AND THREADWORM INFECTIONS AND THEIR ASSOCIATION WITH HEMOGLOBIN AND EOSINOPHIL CONCENTRATIONS IN RESIDENTS OF SALVADOR-BAHIA, BRAZIL
}

Fred Luciano Neves SANTOS (1), Alina Maria Gonzaga Carlos de SOUZA (2) \& Neci Matos SOARES (3)

\begin{abstract}
SUMMARY
Parasitic infections are responsible for substantial mortality and morbidity worldwide. In most healthy individuals, little overt pathology is observed during infection with $S$. stercoralis. However, the symptoms in advanced cases may include gastrointestinal bleeding. Anemia is most commonly associated with hookworm infection, especially when several hundred worms are present. Our study evaluates the relationship between the hookworm or S. stercoralis infection status and the hemoglobin concentration of individuals examined by a private network of laboratories in Salvador, Bahia, Brazil. We examined 374,120 samples from middle-class individuals living in Salvador City from January 2004 to April 2008. The stool samples were analyzed by the Lutz and BaermannMoraes methods, and the blood samples were analyzed for hemoglobin concentration and eosinophil counting. The prevalence of hookworm and S. stercoralis were $0.27 \%(1,027)$ and $0.34 \%(1,286)$, respectively. The prevalence of hookworm and S. stercoralis infection was significantly higher in males than in females and increased with age. Eosinophilia was a common laboratorial finding in individuals infected with hookworm and S. stercoralis. The hemoglobin concentration was lower in the hookworm-infected individuals than in non-infected ones, but none of the examined patients were anemic. Lack of anemia could be a consequence of the socioeconomic status of these patients.
\end{abstract}

KEYWORDS: Hookworms; S. stercoralis; Eosinophilia; Anemia.

\section{INTRODUCTION}

Parasitic infections are responsible for substantial mortality and morbidity worldwide and represent one of the most prevalent pathological phenomena in humans. However, the worldwide distribution of the effect is not uniform, as residents of developing countries are the most impacted $^{29}$. Many parasites are spread through the fecal contamination of food and water. This type of infection occurs most frequently in areas with inadequate sanitation and education. Certain parasites, such as hookworms (Necator americanus and Ancylostoma duodenale) and threadworms (Strongyloides stercoralis), are common species of soiltransmitted helminthes, and infection can cause significant nutritional deficiencies, delayed physical and cognitive development during childhood and reduced productivity in adults ${ }^{15,25,37,47,53}$.

S. stercoralis has a cosmopolitan distribution in tropical and subtropical regions. It is estimated that 100-200 million people are infected worldwide. However, it is likely that this infection rate is underestimated. The diagnosis of strongyloidiasis is difficult because the majority of cases involve the chronic form, low-level infection and very small numbers of larvae intermittently eliminated ${ }^{27,31,43}$.
In a fairly narrow range of conditions, notably in allergic states and infection with helminthes, eosinophil production increases drastically $18,38,46$. According to RANQUE et al. $(1998)^{40}$ and ANANE $(2006)^{3}$, helminth infection should be suspected as the etiology of eosinophilia. In most immunocompetent individuals, S. stercoralis causes little overt pathology, and eosinophilia may be the only symptom ${ }^{5}$. This parasite can persist in the host for decades, leading to the development of gastrointestinal, pulmonary or cutaneous symptoms. Disseminated infection causes severe clinical manifestations and is frequently observed in immunocompromised or malnourished individuals $\mathrm{s}^{5,28,48,52}$.

The association between $S$. stercoralis infection and anemia is rare, except in cases of hyperinfection ${ }^{28,34,39,43,52}$. In contrast, hookworm infection induces iron deficiency, which constitutes one of the world's major nutritional problems ${ }^{2,21,42,49}$. Hookworm infection affects approximately one billion people worldwide, mainly in developing countries. Its prevalence increases with age in children, typically reaching a plateau in late adolescence, whereas the intensity of infection may continue to increase throughout adulthood ${ }^{11}$. The tropical climate of Brazil provides excellent conditions for the development of soiltransmitted helminthes. Therefore, the risk of infection is substantial even for inhabitants who have education and access to health care,

(1) Aggeu Magalhães Research Center (CPqAM), FIOCRUZ, Recife-PE, Brazil.

(2) Datalab Laboratory, Promedica Group, Salvador-BA, Brazil.

(3) Faculty of Pharmacy, Federal University of Bahia, Salvador-BA, Brazil.

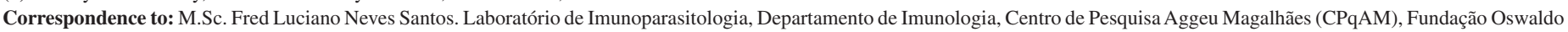

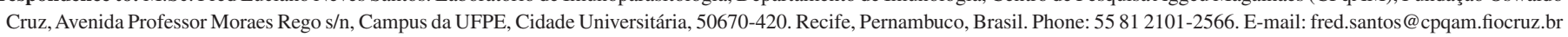




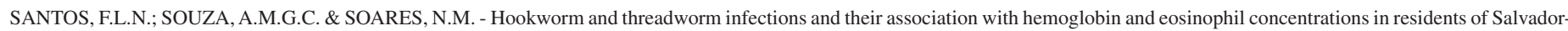
Bahia, Brazil. Rev. Inst. Med. Trop. Sao Paulo, 55(4): 233-8, 2013.

although there is a lack of epidemiological studies on this population. The relationship between helminth infection and anemia has been demonstrated in epidemiological studies ${ }^{21,33,49,51}$, mainly in patients with a high worm burden ${ }^{50}$.

We conducted an analytical, cross-sectional study of helminth infections (hookworms and S. stercoralis) and the relationship between hemoglobin concentration and eosinophilia among individuals analyzed by a private network of laboratories in Salvador, Bahia, Brazil.

\section{MATERIALS AND METHODS}

Study population: This study was conducted between January 2004 and April 2008. Samples were collected from individuals attending a routine laboratory service in Salvador City, Brazil. Stool samples were analyzed from 374,120 patients with a mean age of 34.04 years, all living in Salvador City and the surrounding metropolitan area. The laboratory network is composed of 11 posts throughout Salvador and its metropolitan region and serves the socioeconomically higher segment of the population, which has access to basic sanitation, a good nutritional status and income averaging five times the minimum wage. Salvador is the third most populous city in Brazil and the ninth in Latin America, with a population of $2,675,656^{26}$. It has a warm and humid tropical rainforest climate with no discernible dry season and temperatures that are relatively constant throughout the year, which is conducive to the growth of soil-transmitted helminthes.

Samples processing: A single fresh stool specimen from each patient was analyzed by both the BAERMANN-MORAES ${ }^{6,36}$ and LUTZ $^{32}$ methods. In this study, monoinfected patients were defined as individuals of either sex with stool samples that were either positive for hookworms as diagnosed by spontaneous sedimentation, or positive for S. stercoralis as diagnosed by the Baermann-Moraes technique. Poliparasited individuals were excluded from the study. Healthy patients were defined as individuals with negative results for eggs and larvae of helminthes, and cysts or trophozoites of protozoan. Knowledge of the age and sex of the patients and an adequate quantity of stool for diagnosis by both methods were the minimum inclusion criteria.

The hemoglobin concentration was measured using an automated method (Sysmex XT-2000i, Roche). According to the hemoglobin concentration, patients were divided into five groups as follows: infant $(<$ 2 years; reference range: hemoglobin $>10.5 \mathrm{~g} / \mathrm{dL}$ ); preschool (2-6 years;

reference range: hemoglobin $>11.5 \mathrm{~g} / \mathrm{dL}$ ); schoolchild (7-12 years; reference range: $>11.5 \mathrm{~g} / \mathrm{dL})$; teenager (13-18 years; reference range for males: $>13.0 \mathrm{~g} / \mathrm{dL}$; reference range for females: $>12 \mathrm{~g} / \mathrm{dL}$ ); and adult (> 19 years; reference range for males: $>13.5 \mathrm{~g} / \mathrm{dL}$; reference range for females: $>12.0 \mathrm{~g} / \mathrm{dL})^{17}$. To examine the red blood cell morphology, the smear was stained with panoptic dye and the white blood cells were counted. An eosinophil count less than $5 \%$ or $500 / \mathrm{mm}^{3}$ was considered to be normal ${ }^{17}$.

Statistical analysis: The data were managed and analyzed using the Statistical Package for the Social Sciences (SPSS) 15.0 Chicago software. The variables were compared using the Student's t-test and the Mann-Whitney test. A two-tailed $p$-value less than 0.05 was considered to be significant.

\section{RESULTS}

Stool samples of 374,120 patients, examined by the spontaneous sedimentation and Baermann-Moraes techniques, revealed infection rates of $0.27 \%(1,027)$ for hookworm and $0.34 \%(1,286)$ for S. stercoralis. The prevalence of hookworm and S. stercoralis infection was significantly higher in males than in females $(75.8 \%$ vs. $24.2 \%, p<0.001 ; 78.6 \%$ vs. $21.4 \%, p<0.001$, respectively), and the prevalence of hookworm and $S$. stercoralis infection increased with age (Table 1). These prevalences ranged from $0.44 \%$ to $0.20 \%$ and from $0.42 \%$ to $0.27 \%$ for hookworms and S. stercoralis, respectively, over the four-year course of this study (Fig. 1). The stool samples were categorized by calendar month to evaluate seasonal variation over the years. The mean infection rates for each of the 52 months comprising the study period were computed separately. To assess the statistical significance of the differences in infection rates between 12 calendar-year months, we combined the total number of specimens listed and the total number of positive specimens for each month across each of the 4.4 study years. The overall rates for hookworm infection ranged from a low of $0.18 \%$ (September) to a high of $0.37 \%$ (June). Similar results were observed for S. stercoralis infection, in which the positivity rates ranged from $0.25 \%$ (September) to $0.43 \%$ (July) (Fig. 2). Statistical analyses indicated that the monthly infection rates did not vary considerably over time.

The hemoglobin concentration $(\mathrm{g} / \mathrm{dL})$ was normal for all of the groups of hookworm- and S. stercoralis-infected individuals. Neither hookworm nor $S$. stercoralis infections were associated with any risk of decreased hemoglobin levels $(\mathrm{OR}=1.1195 \% \mathrm{CI}=0.86-1.43)$ and 1.12 (95\% CI 0.87-1.45), respectively.

Table 1

Prevalence of hookworm and Strongyloides stercoralis infections in 374,120 individuals from Salvador, Bahia, Brazil, according to age and sex

\begin{tabular}{|c|c|c|c|c|c|c|}
\hline \multirow{2}{*}{ Age (years) } & \multicolumn{3}{|c|}{ Hookworms } & \multicolumn{3}{|c|}{ S. stercoralis } \\
\hline & Males & Females & Total & Males & Females & Total \\
\hline$<2$ & $3(0.3)$ & 0 & $3(0.3)$ & 0 & 0 & 0 \\
\hline $2-6$ & $14(1.4)$ & $4(0.3)$ & $18(1.7)$ & $10(0.8)$ & $5(0.4)$ & $15(1.2)$ \\
\hline $7-12$ & $27(2.6)$ & $14(1.4)$ & $41(4.0)$ & $15(1.2)$ & $8(0.6)$ & $23(1.8)$ \\
\hline $13-18$ & $27(2.6)$ & $21(2.0)$ & 48 (4.6) & $11(0.9)$ & $2(0.1)$ & $13(1.0)$ \\
\hline$>19$ years & 707 (68.9) & $210(20.5)$ & 917 (89.4) & $975(75.7)$ & $260(20.3)$ & 1,235 (96.0) \\
\hline Totals & $778(75.8)^{\mathrm{a}}$ & $249(24.2)^{\mathrm{a}}$ & $1,027(100)$ & $1,011(78.6)^{\mathrm{a}}$ & $275(21.4)^{\mathrm{a}}$ & $1,286(100)$ \\
\hline
\end{tabular}

${ }^{a} p<0.05$. Statistic difference between males and females groups (Student's t-test). 


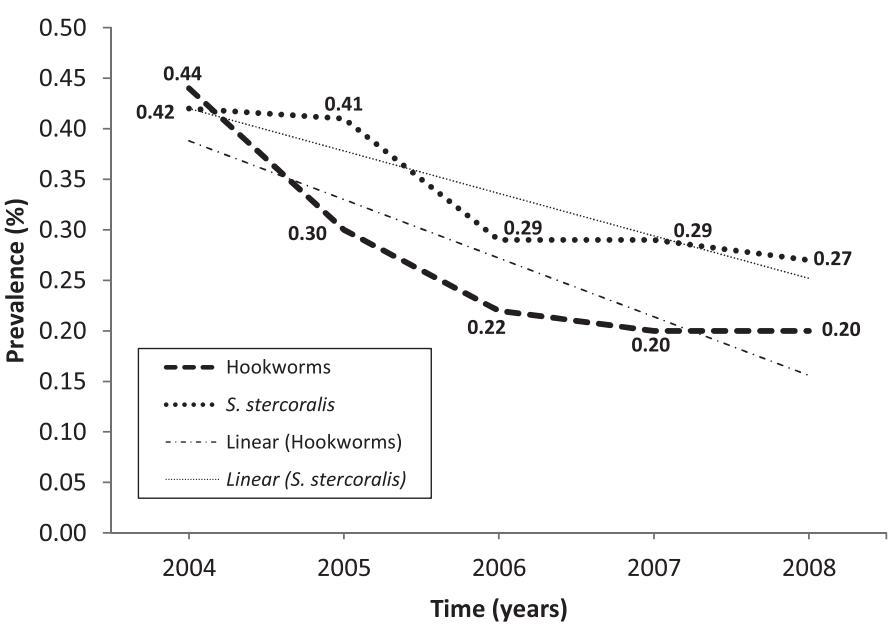

Fig. 1 - Prevalence of hookworms and S. stercoralis in individuals attending a laboratory network from Salvador, Bahia, Brazil $(\mathrm{n}=374,120)$.

The increase in the blood eosinophil levels in hookworm- $(\mathrm{OD}=$ $6.4695 \% \mathrm{CI}=5.46-7.64)$ and $S$. stercoralis-infected individuals $(\mathrm{OD}=$ $10.4595 \% \mathrm{CI}=8.87-12.30)(p<0.01)$ is shown in Table 3 .

\section{DISCUSSION}

Helminthic infections are widely distributed throughout tropical and

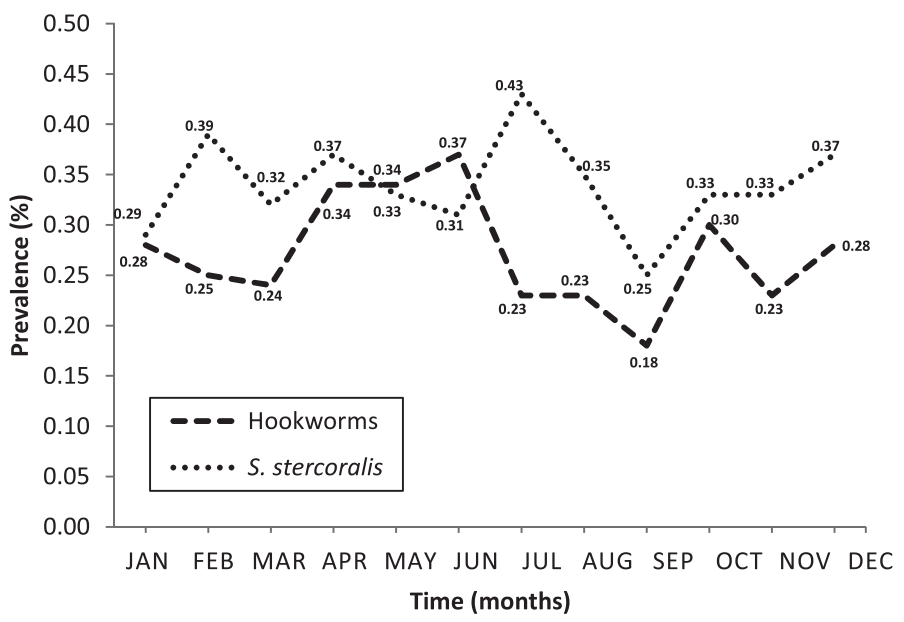

Fig. 2 - Mensal prevalence of hookworm and S. stercoralis infection in 374,120 individuals attending a laboratory network from Salvador, Bahia, Brazil, based on the mean obtained for each month in the 52 months of the study (January 2004 - April 2008).

subtropical areas, particularly in developing countries where sanitary education actions are ineffective. This study evaluated the prevalence of hookworm and S. stercoralis in 374,120 patients. Of these, 1,027 $(0.27 \%)$ patients were positive for hookworm and 1,286 (0.34\%) patients were positive for $S$. stercoralis. These data are similar to those obtained by an investigation conducted in São Paulo City studying a population

Table 2

Hemoglobin levels (g/dL) in hookworm- and S. stercoralis-infected patients compared with a healthy control group

\begin{tabular}{|c|c|c|c|c|c|c|c|}
\hline \multirow{2}{*}{ Variables } & & \multicolumn{2}{|c|}{ Hookworms } & \multicolumn{2}{|c|}{ S. stercoralis } & \multicolumn{2}{|c|}{ Uninfected group } \\
\hline & & $\mathrm{n}$ & $\mathrm{Hb}$ & $\mathrm{n}$ & $\mathrm{Hb}$ & $\mathrm{n}$ & $\mathrm{Hb}$ \\
\hline \multirow[t]{2}{*}{ Infant } & Male & 3 & 12.6 & 0 & - & 642 & 12.2 \\
\hline & Female & 0 & - & 0 & - & 613 & 12.1 \\
\hline \multirow[t]{2}{*}{ Preschool } & Male & 7 & $12.2 *$ & 5 & 12.6 & 9,385 & 12.4 \\
\hline & Female & 3 & 12.9 & 4 & 11.9 & 8,559 & 12.4 \\
\hline \multirow{2}{*}{$\begin{array}{l}\text { Schoolchil- } \\
\text { dren }\end{array}$} & Male & 22 & 12.7 & 13 & 13.1 & 10,465 & 13.0 \\
\hline & Female & 13 & $12.0^{\mathrm{a}}$ & 5 & 12.1 & 10,318 & 13.0 \\
\hline \multirow[t]{2}{*}{ Teenage } & Male & 21 & 13.8 & 9 & 14.2 & 6,364 & 13.9 \\
\hline & Female & 12 & 13.6 & 2 & 12.6 & 6,328 & 13.1 \\
\hline \multirow[t]{2}{*}{ Adult } & Male & 605 & $14.8^{\mathrm{a}}$ & 838 & $14.7^{\mathrm{a}}$ & 65,050 & 15.0 \\
\hline & Female & 164 & 13.2 & 196 & 13.3 & 92,024 & 13.2 \\
\hline
\end{tabular}

Infant ( $<2$ years); Preschool (2-6 years); Schoolchild ( $7-12$ years); Teenager (13-18 years); Adult ( $>19$ years). ${ }^{a} p<0.05$. Statistic difference between infected and non-infected groups (Mann-Whitney and Student's t-test); $\mathrm{Hb}=$ Hemoglobin level.

Table 3

Eosinophil levels in hookworm-infected patients compared to a healthy group

\begin{tabular}{|c|c|c|c|c|c|c|c|}
\hline \multirow{2}{*}{ Variables } & \multicolumn{2}{|c|}{ Hookworms } & \multicolumn{2}{|c|}{ S. stercoralis } & \multicolumn{2}{|c|}{ Uninfected group } & \multirow[t]{2}{*}{$p$ value } \\
\hline & $\mathrm{n}$ & EOS & $\mathrm{n}$ & EOS & $\mathrm{n}$ & EOS & \\
\hline Male & 632 & 10.12 & 843 & 11.34 & 125,244 & 5.11 & $0.000 *$ \\
\hline Female & 183 & 8.35 & 210 & 10.50 & 148,816 & 3.78 & $0.000 *$ \\
\hline
\end{tabular}

*Student's t-test. EOS = Eosinophil count. 


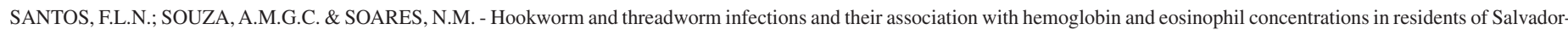
Bahia, Brazil. Rev. Inst. Med. Trop. Sao Paulo, 55(4): 233-8, 2013.

with access to health care ${ }^{35}$. Other projects in several regions of Brazil showed $1.7 \%$ in patients in Aracaju (Sergipe State) ${ }^{53} ; 2.3 \%$ in patients living in Salvador (Bahia) proceeding from the Public Health System ${ }^{44}$; $2.9 \%$ in patients in Minas Gerais State ${ }^{14} ; 6.6 \%$ in patients in Ipirá City (Bahia State) ${ }^{45} ; 9.0 \%$ in patients in the Amazon region ${ }^{4}$; and $15.3 \%$ in children living in municipalities with low human development indices in North and Northeast Brazil ${ }^{19}$. On the other hand, other authors found as high a prevalence as $88.4 \%$ of inhabitants of four villages in São Lourenço da Mata (Pernambuco State) ${ }^{23}$ and $91.9 \%$ of inhabitants of Ilha da Marambaia (Rio de Janeiro State) ${ }^{16}$. With regard to S. stercoralis prevalence, our results are comparable to those of MONTEIRO et al. $(1988)^{35}$ obtained in São Paulo City (0.3\%), ROCHA et al. $(2000)^{41}$ in the town of Bambuí, Minas Gerais State $(0.2 \%)$, and ARAÚJO \& FERNÁNDEZ $(2005)^{4}$ in the Amazon region (1.0\%). The observed differences in hookworm prevalence could be explained by the fact that the studies were conducted in distinct areas and on different populations with varied exposure to risk factors and socioeconomic status. In fact, a study has shown that the income level of a population influences the distribution of intestinal helminths ${ }^{1}$. SANTOS et al. $(2007)^{44}$ observed that the prevalence of S. stercoralis in patients from the Public Health System $(4.6 \%)$ was 7.7 times higher than that of those attended to by the Private Health System $(0.6 \%)$.

Infections by hookworms and $S$. stercoralis were associated with age and sex. The 30- to 50-year age group was the most commonly infected by hookworms, and the 40- to 60-year age group was the most commonly infected by $S$. stercoralis. Children can be infected with hookworms and $S$. stercoralis at an age as young as six months, and this infection prevalence increases with age, plateauing in adulthood ${ }^{11}$. In this study, the youngest infected patient was eight months old. The highest prevalence was observed in adulthood. However, different results have been observed by others worldwide. In China and Southeast Asia, the highest prevalence was observed in the middle-aged or even in individuals over 60 years old $^{8,10,20,30}$. Such age profiles of hookworms contrast to the rapid increase in prevalence of Ascaris lumbricoides and Trichuris trichiura, for which the prevalence reaches a maximum in 5- to 10-year-olds and remains relatively stable throughout adulthood ${ }^{12}$.

In accordance with other infectious diseases, it has been suggested that males are more commonly infected with hookworm and S. stercoralis than females ${ }^{13,22}$. It is likely that this discrepancy arises because males perform more activities that lead to greater risk of exposure ${ }^{8}$. However, other factors may contribute to susceptibility to infections, such as immunological response and nutritional status ${ }^{12}$. Our results also demonstrated that infections with hookworm and S. stercoralis are more common in males than in females, possibly due to the higher risk of exposure of males.

In the last year of the study, we observed an apparent decrease in the prevalence of both helminthes. From 2004 to 2008, the hookworm prevalence decreased by $0.24 \%$ (from 0.44 to $0.20 \%$ ), and the $S$. stercoralis prevalence decreased by $0.15 \%$ (from 0.42 to $0.27 \%$ ). This decrease could be explained by the positive impact of a project called Bahia Azul ${ }^{7}$. This program was implemented in 1996 to improve sanitation infrastructure and environmental preservation. The reduction in prevalence between time periods showed that changes in environmental health significantly decreased the occurrence of intestinal parasites in residents from Salvador City and its metropolitan area.
The most serious cause of iron loss from the body is chronic hemorrhage; estimates show that a blood loss of $15-20 \mathrm{~mL}$ per day into the lumen of the small intestine results in a state of negative iron balance. Ancylostoma duodenale and Necator americanus have been estimated to cause a daily loss into the small intestine of $0.14-0.26$ $\mathrm{mL}$ and $0.02-0.07 \mathrm{~mL}$ per worm, respectivel $\mathrm{y}^{54}$. When several hundred hookworms are present in the small intestine, the daily blood loss is sufficient to cause anemia, even in well-nourished children or adults ${ }^{54}$. We observed that the hemoglobin level of certain infected groups was less than that observed in the corresponding uninfected group $(p<$ 0.05 ). Nevertheless, no anemia case was verified (hemoglobin $<10$ $\mathrm{g} / \mathrm{dL}$ ). We believe that the values of hemoglobin found are consistent with patients from the upper and middle classes, who have access to education, iron-rich foods and health programs. Controversially, the S. stercoralis-infected groups were not significantly different from the control group, except the adult male group. The development of anemia in $S$. stercoralis-infected individuals is correlated with alcoholism, malnutrition, the breakdown of local immune responses, and/or alterations in intestinal barriers ${ }^{24,39,52}$. Our population is characterized by a high socioeconomic status with access to basic sanitation and a good nutritional status.

An increase in the peripheral blood eosinophils has long been recognized as a characteristic feature of helminth infection, consumption of medications, allergic disorders, and autoimmune and malignant diseases ${ }^{18,34,38,46}$. However, parasitic infection is the major cause of eosinophilia in developing countries. In healthy individuals, eosinophils comprise approximately $1-5 \%$ of white blood cells. In this study, the majority of infected patients exhibited higher percentages than uninfected patients; $10.12 \%$ (male) and $8.35 \%$ (female) to hookworm, and $11.34 \%$ (male) and $10.50 \%$ (female) to S. stercoralis-infections.

It is widely accepted that helminths and their antigens induce the $\mathrm{T}$ helper cell type 2 (Th 2 ) response, resulting in the production of interleukin (IL)-4, IL-5 and consequently the development of strong immunoglobulin E (IgE), eosinophil and mast cell responses. The eosinophils release large amounts of potent mediators, such as major basic protein, eosinophil cationic protein, eosinophil peroxidase, and eosinophil neurotoxin, all of which may directly damage tissues in addition to damaging the infectious worms ${ }^{9,18,38}$. Perhaps the increase in peripheral blood eosinophils in infected patients reflects the control of the infection but is not in itself sufficient to eliminate the parasite.

We conclude the following: (1) The prevalences of hookworm and S. stercoralis were $0.27 \%$ and $0.34 \%$, respectively, and infection was more frequent in adults (21-60 years) and in males; (2) The hemoglobin concentration was lower in the hookworm-infected group than in the uninfected group, whereas a decrease in the hemoglobin levels of S. stercoralis-infected patients was shown only in adult males; (3) Eosinophilia is a common secondary diagnosis in hookworm- and S. stercoralis-infected patients; and (4) Anemia was not observed in any hookworm-infected patient, most likely as a result of their high socioeconomic status.

\section{CONFLICT OF INTEREST}

The authors declare that there is no conflict of interest. 


\section{RESUMO}

\section{Associação entre infecções por ancilostomídeos e Strongyloides stercoralis e concentração de hemoglobina e eosinófilos em residentes de Salvador-Bahia, Brasil}

As infecções parasitárias são responsáveis por importantes quadros de morbimortalidade em todo o mundo. A maioria dos indivíduos saudáveis infectados pelo $S$. stercoralis não apresenta sintomas clínicos evidentes. Entretanto, em casos mais avançados sangramentos gastrintestinais podem estar presentes. A anemia é mais comumente associada à infecção causada pelos ancilostomídeos, especialmente quando centenas de vermes estão presentes. Neste trabalho, a associação entre infecções causadas por ancilostomídeos ou $S$. stercoralis e as concentrações de hemoglobina e de eosinófilos foi investigada em indivíduos atendidos em uma rede de laboratórios de Salvador, Bahia, Brasil. Foram examinadas 374.120 amostras de indivíduos de classe média residentes na cidade de Salvador, de janeiro de 2004 a abril de 2008. As amostras de fezes foram analisadas pelos métodos de Lutz e Baermann-Moraes e as de sangue foram avaliadas para determinação da concentração de hemoglobina e do número de eosinófilos. A prevalência de ancilostomídeos e de S. stercoralis foi de $0,27 \%$ (1.027) e $0,34 \%$ (1.286) respectivamente. A prevalência de infecções, tanto por ancilostomídeos quanto por $S$. stercoralis, foi significativamente maior em homens que em mulheres e aumentava com o aumento da idade. A eosinofilia foi um achado comum tanto em indivíduos infectados por ancilostomídeos como por Strongyloides. A concentração de hemoglobina foi menor nos indivíduos infectados por ancilostomídeos quando comparado aos indivíduos não infectados, embora nenhum paciente apresentasse anemia. A ausência de anemia pode ser devida às boas condições socioeconômicas dos pacientes analisados.

\section{REFERENCES}

1. Agbaya SSO, Yavo W, Menan EIH, Attey MA, Kouadio LP, Koné M. Helminthiases intestinales chez les enfants d'âge scolaire: résultats préliminaires d'une étude prospective à Agboville dans le sud de la Côte d'Ivoire. Santé. 2004;14:143-7.

2. Albonico M, Crompton DW, Savioli L. Control strategies for human intestinal nematode infections. Adv Parasitol. 1999;42:277-341.

3. Anane S. Les étiologies parasitaires d'une hyperéosinophilie sanguine. Ann Biol Clin. 2006;64:219-29.

4. Araujo CF, Fernández CL. Prevalência de parasitoses intestinais na cidade de Eirunepé, Amazonas. Rev Soc Bras Med Trop. 2005;38:69.

5. Ardiç N. An overview of Strongyloides stercoralis and its infections. Mikrobiyol Bul. 2009;43:169-77.

6. Baermann G. Eine einfache methode zur auffindung vor Ankylostomum (Nematoden). Larven in Erdproben. Mededeel mit H. Geneesk. Batavia, Lab. Weltevreden Feestbundel. 1917;41-7.

7. Barreto ML, Genser B, Strina A, Teixeira MG, Assis AMO, Rego RF, et al. Effect of citywide sanitation programme on reduction in rate of childhood diarrhoea in northeast Brazil: assessment by two cohort studies. Lancet. 2007;370:1622-8.

8. Behnke JM, De Clercq D, Sacko M, Gilbert FS, Ouattara DB, Vercruysse J. The epidemiology of human hookworm infections in the southern region of Mali. Trop Med Int Health. 2000;5:343-54.
9. Bejon P, Mwangi TW, Lowe B, Peshu N, Hill AVS, Marsh K. Helminth infection and eosinophilia and the risk of Plasmodium falciparum malaria in 1- to 6-year-old children in a malaria endemic area. PLoS Negl Trop Dis. 2008;2:e164.

10. Bethony J, Chen J, Lin S, Xiao S, Zhan B, Li S, et al. Emerging patterns of hookworm infection: influence of aging on the intensity of Necator infection in Hainan Province, People's Republic of China. Clin Infect Dis. 2002;35:1336-44.

11. Brooker S, Peshu N, Warn PA, Mosobo M, Guyatt HL, Marsh K, et al. The epidemiology of hookworm infection and its contribution to anaemia among pre-school children on the Kenyan coast. Trans R Soc Trop Med Hyg. 1999;93:240-6.

12. Brooker S, Bethony J, Hotez PJ. Human hookworm infection in the $21^{\text {st }}$ century. Adv Parasitol. 2004;58:197-288.

13. Bundy DA. Sexual effects on parasite infection. Parasitol Today. 1988;4:186.

14. Carvalho O dos S, Guerra HL, Campos YR, Caldeira RL, Massara CL. Prevalence of intestinal helminths in three regions of Minas Gerais State. Rev Soc Bras Med Trop. 2002;35:597-600.

15. Chan MS, Nsowah-Nuamah NN, Adjei S, Wen ST, Hall A, Bundy DA. Predicting the impact of school-based treatment for urinary schistosomiasis given by the Ghana Partnership for Child Development. Trans R Soc Trop Med Hyg. 1998;92:386-9.

16. Coronato B, Bastos OMP, Duarte R, Duarte AN, Laurentino-Silva V, Souza MB, et al. Parasites in stool samples in the environment of Ilha da Marambaia, Rio de Janeiro, Brazil: an approach in public health. Rev Inst Med Trop Sao Paulo. 2012;54:65-8.

17. David GN, Orkin S, Look AT, Ginsburg D, editors. Nathan and Oski's hematology of infancy and childhood. Philadelphia: WB Saunders; 2003.

18. Dixon H, Blanchard C, Deschoolmeester ML, Yuill NC, Christie JW, Rothenberg ME, et al. The role of Th2 cytokines, chemokines and parasite products in eosinophil recruitment to the gastrointestinal mucosa during helminth infection. Eur J Immunol. 2006;36:1753-63.

19. Fonseca EOL, Teixeira MG, Barreto ML, Carmo EH, Costa MCN. Prevalência e fatores associados às geo-helmintíases em crianças residentes em municípios com baixo IDH no Norte e Nordeste brasileiros. Cad Saúde Pública. 2010;26:143-52.

20. Gandhi NS, Jizhang C, Khoshnood K, Fuying X, Shanwen L, Yaoruo L, et al. Epidemiology of Necator americanus hookworm infections in Xiulongkan Village, Hainan Province, China: high prevalence and intensity among middle-aged and elderly residents. J Parasitol. 2001;87:739-43.

21. Gilles HM, Williams EJ, Ball PA. Hookworm infection and anemia. An epidemiological, clinical, and laboratory study. Q J Med. 1964;33:1-24.

22. Goble F, Konopka E. Sex as a factor in infectious disease. Trans N Y Acad Sci. $1971 ; 35: 325-46$

23. Gonçalves JF, Tanabe M, Medeiros FPM, Gonçalves FJ, Aca IS, Motta SRN, et al. Estudos sorológicos e parasitológicos na amebíase e em outras infecções parasito-intestinais no setor rural dos arredores de Recife, nordeste do Brasil. Rev Inst Med Trop Sao Paulo. 1990;32:428-35.

24. Hira PR, Al-Ali F, Shweiki HM, Abdella NA, Johny M, Francis I, et al. Strongyloidiasis: challenges in diagnosis and management in non-endemic Kuwait. Ann Trop Med Parasitol. 2004;98:261-70.

25. Hotez PJ. Mass drug administration and integrated control for the world's high-prevalence neglected tropical diseases. Clin Pharmacol Ther. 2009;85:659-64.

26. IBGE. Censo 2010. Brasília: IBGE; 2010. [cited 2012 June 30]. Available from: http:// www.censo2010.ibge.gov.br. 
SANTOS, F.L.N.; SOUZA, A.M.G.C. \& SOARES, N.M. - Hookworm and threadworm infections and their association with hemoglobin and eosinophil concentrations in residents of SalvadorBahia, Brazil. Rev. Inst. Med. Trop. Sao Paulo, 55(4): 233-8, 2013.

27. Inês EJ, Souza JN, Santos RC, Souza ES, Santos FLN, Silva MLS, et al. Efficacy of parasitological methods for the diagnosis of Strongyloides stercoralis and hookworm in faecal specimens. Acta Trop. 2011;120:206-10.

28. Keiser PB, Nutman TB. Strongyloides stercoralis in the immunocompromised population. Clin Microbiol Rev. 2004;17:208-17.

29. Latham MC. Strategies for the control of malnutrition and the influence of the nutritional sciences. Food Nutr (Roma). 1984;10:5-31.

30. Lili Z, Bingxiang Z, Hong T, Shuhua X, Hotez P, Bing Z, et al. Epidemiology of human geohelminth infections (ascariasis, trichuriasis and necatoriasis) in Lushui and Puer Counties, Yunnan Province, China. Southeast Asian J Trop Med Public Health. 2000;31:448-53.

31. Liu LX, Weller PF. Strongyloidiasis and other intestinal nematode infections. Infect Dis Clin North Am. 1993;7:655-82.

32. Lutz A. O Schistosomum mansoni e a Schistosomatose segundo observações feitas no Brazil. Mem Inst Oswaldo Cruz. 1919;11:121-55.

33. Martinez-Torres C, Ojeda A, Roche M, Layrisse M. Hookworm infection and intestinal blood loss. Trans R Soc Trop Med Hyg. 1967;61:373-83.

34. Mascarello M, Gobbi F, Angheben A, Gobbo M, Gaiera G, Pegoraro M, et al. Prevalence of Strongyloides stercoralis infection among HIV-positive immigrants attending two Italian hospitals, from 2000 to 2009. Ann Trop Med Parasitol. 2011;105:617-23.

35. Monteiro CA, Chieffi PP, Benicio MH, Dias RM, Torres DM, Mangini AC. Estudo das condições de saúde das crianças do Município de São Paulo (Brasil), 1984/1985. VII - Parasitoses intestinais. Rev Saúde Pública. 1988;22:8-15.

36. Moraes RG. Contribuição para o estudo do Strongyloides stercoralis e da estrongiloidíase no Brasil. Rev Serv Esp Saúde Pública. 1948;1:507-624.

37. Müller I, Coulibaly JT, Fürst T, Knopp S, Hattendorf J, Krauth SJ, et al. Effect of schistosomiasis and soil-transmitted helminth infections on physical fitness of school children in Côte d'Ivoire. PLoS Negl Trop Dis. 2011;5:e1239.

38. Ovington KS, Behm CA. The enigmatic eosinophil: investigation of the biological role of eosinophils in parasitic helminth infection. Mem Inst Oswaldo Cruz. 1997;92(Suppl 2):93-104.

39. Potter A, Stephens D, De Keulenaer B. Strongyloides hyper-infection: a case for awareness. Ann Trop Med Parasitol. 2003;97:855-60.

40. Ranque S, Candolfi E, Himy R. Diagnosis and management of parasitic hypereosinophilia. Presse Med. 1998;27:370-5.
41. Rocha RS, Silva JG, Peixoto SV, Caldeira RL, Firmo JO, Carvalho OS, et al. Avaliação da esquistossomose e de outras parasitoses intestinais, em escolares do município de Bambuí, Minas Gerais, Brasil. Rev Soc Bras Med Trop. 2000;33:431-6.

42. Roche M, Layrisse M. The nature and causes of "hookworm anemia". Am J Trop Med Hyg. 1966;15:1029-102.

43. Roxby AC, Gottlieb GS, Limaye AP. Strongyloidiasis in transplant patients. Clin Infect Dis. 2009; 49:1411-23.

44. Santos LP, Santos FLN, Soares NM. Prevalência de parasitoses intestinais em pacientes atendidos no Hospital Universitário Professor Edgar Santos, Salvador-Bahia. Rev Pat Trop. 2007;36:237-46.

45. Santos-Júnior GO, Silva MM, Santos FLN. Prevalência de enteroparasitoses em crianças do sertão baiano pelo método de sedimentação espontânea. Rev Pat Trop. 2006;35:233-40.

46. Shin MH, Lee YA, Min DY. Eosinophil-mediated tissue inflammatory responses in helminth infection. Korean J Parasitol. 2009;47(Suppl):S125-31.

47. Stephenson LS. Helminth parasites, a major factor in malnutrition. World Health Forum. 1994;15:169-72.

48. Stephenson LS, Latham MC, Ottesen EA. Malnutrition and parasitic helminth infections. Parasitology. 2000;121(Suppl):S23-38.

49. Stoltzfus RJ, Albonico M, Chwaya HM, Savioli L, Tielsch J, Schulze K, et al. Hemoquant determination of hookworm-related blood loss and its role in iron deficiency in African children. Am J Trop Med Hyg. 1996;55:399-404

50. Stoltzfus RJ, Dreyfuss ML, Chwaya HM, Albonico M. Hookworm control as a strategy to prevent iron deficiency. Nutr Rev. 1997;55:223-32.

51. Strickland GT, editor. Hunter's tropical medicine and emerging infectious diseases. Philadelphia: Saunders; 2000 .

52. Teixeira MCA, Inês EJ, Pacheco FTF, Silva RK, Mendes AV, Adorno EV, et al Asymptomatic Strongyloides stercoralis hyperinfection in an alcoholic patient with intense anemia. J Parasitol. 2010;96:833-5.

53. Tsuyuoka R, Bailey JW, Nery Guimarães AM, Gurgel RQ, Cuevas LE. Anemia and intestinal parasitic infections in primary school students in Aracaju, Sergipe, Brazil. Cad Saúde Pública. 1999;15:413-21.

54. WHO Expert Commitee. Public health significance of intestinal parasitic infections. Bull World Health Organ. 1987;65:575-88.

Received: 20 July 2012

Accepted: 4 December 2012 